ISSN: 2146-3042

DOI: $10.25095 /$ mufad.710380

\title{
Future Expectations in Banking Risk Management*
}

\author{
Sezer BOZKUŞ KAHYAOĞLU** \\ Ganite KURT***
}

\begin{abstract}
This paper focuses on risk organizations in banks and specifically the risk management function of banks. In order to forecast the future dynamics and expectations of stakeholders, the milestones of risk management are analyzed based on relevant literature. The development of banking risk management over the last ten years has been a response to the direct financial impact of the crisis and to the regulatory agenda that followed. This study argues that a new hybrid type of banking system, in which financial engineering and the integration of products and services from outside suppliers play a greater role than ever before, is emerging. After the global financial crisis, particularly banks' risk organizations have grown as they have reshaped themselves by going beyond the management of traditional financial risks. In addition, banks' balance sheets and funding strategies have changed dramatically since 2007, with higher (equity) capital ratios and more stable debt funding. In this context, banks attach special importance to risk organization, risk culture and control activities in order to develop risk intelligence.
\end{abstract}

Keywords: Risk Committee, Risk Culture, Risk Intelligence, Chief Risk Officer.

JEL Classification: $G 21, G 32, C 58$

\section{Banka Risk Yönetiminde Gelecek Beklentileri}

ÖZET

Bu makale, bankalardaki risk örgülenmesine ve özellikle bankaların risk yönetimi işlevine odaklanmaktadır. Paydaşların gelecekteki dinamiklerini ve beklentilerini tahmin etmek için, risk yönetiminin kilometre taşları ilgili literatüre dayalı olarak ele alınmaktadır. Bankacılık risk yönetiminin son on yıldaki gelişimi, küresel krizin doğrudan finansal etkisine ve ardından gelen düzenleyici gelişmelere bir cevap niteliğinde olmuştur. Bu çalışma, finansal mühendisliğin ve dış tedarikçi firmalardan ürün ve hizmetlerin entegrasyonunun öncekinden daha büyük bir rol oynadığ yeni bir hibrid bankacılık sistemi türünün ortaya çıktığını ortaya koymaktadır. Küresel finansal krizden sonra, özellikle bankaların risk örgütlenmeleri, geleneksel finansal risklerin yönetiminin ötesine geçerek kendilerini yeniden şekillendirdikleri için hızlı büyümüştür. Bu bağlamda, bankaların bilançoları ve fonlama stratejileri 2007'den bu yana önemli ölçüde değişim göstererek, yüksek (özkaynak) sermaye oranları ve daha istikrarlı borç finansmanı şeklinde oluşmuştur. Bu kapsamda, bankalar risk zekasını geliştirmek için risk örgütlenmesine, risk kültürüne ve kontrol faaliyetlerine özel önem vermektedir.

Anahtar Kelimeler: Risk Komitesi, Risk Kültürü, Risk Zekası, Risk Yöneticisi

Jel Sınıflandırması: G21, G32, C58.

\footnotetext{
* This is the improved and revised version of study, which was originally presented in the 1 st International Banking Conference in Ankara 4-5 May 2018

Makale Gönderim Tarihi: 28.06.2019, Makale Kabul Tarihi: 09.10.2019, Makale Türü: Kuramsal Makale

** Associate Prof., Izmir Bakırçay University, Faculty of Economics and Social Sciences, CIA, CFE, CFSA, CRMA, CICP, KGK-BD, SMMM, sezer.bozkus@bakircay.edu.tr , Orcid ID: orcid.org/0000-0003-2865-3399.

*** Prof., Ankara Hacı Bayram Veli University, Banking and Insurance College, ganitekurt@gmail.com, Orcid ID: orcid.org/0000-0001-6438-2501.
} 


\section{INTRODUCTION}

Risk management is outlined as a range of financial or operational actions that maximize the value of an organization or a portfolio by minimizing the costs regarding the cash flow volatility (Stulz 1996: 8-10; 2003:35-38). In general, the method used in the analysis and measurement of risks focuses on the probability of occurrence and the impact of the risk and the negative consequences of the risks are emphasized. Risk can be measured by volatility of outcomes and in order to do this, higher moments of the volatility distribution are required for calculations (Bozkuş, 2005: 28-30).

The main purpose of risk management is to enable organizations to develop a strategy against uncertainties, risks and all kinds of threats, and in some cases to demonstrate the ability to turn such events into opportunities. Risks are inherent in all kinds of economic and financial activities of all institutions. The risk identification, evaluation, and governance process is part of organizations' strategic build-up; for this reason, it must be planned and conducted at the top level, at least the directorate (Jorion, 2006: 20-28; COSO, 2017: 3-6). In addition, it is possible to manage internal dependencies while analyzing, measuring and monitoring risks through integrated risk management developed to increase the effectiveness of risk management.

After the global financial crisis, the risk appetites of banks have decreased significantly which led to limited access to traditional bank intermediated lending. Over the same period, there is a tremendous increase in the alternative lending platforms leveraging P2P models (Aveni, 2015:10-12). These lending platforms usually apply alternative settlement and mediation approaches based on automated processes to provide loans to a broader range of customers. In addition, there is a new class of investment opportunities to savers. The key implications of new business environment could be the emerging alternative lending models, which bring both competitive threats and evolutionary opportunities for financial institutions. Therefore, it is crucial for banks to have alternative platforms to develop partnerships that are more integrated and learn from and share each other's capabilities (Garisde and Mitchell, 2017: 8-9).

This study analyzes the innovations in the field of banking risk management and evaluates the constructive and destructive aspects. Thus, the effects of the developments, that are realized and expected to occur on the risk management structure in banks, are revealed. Although the study is not an empirical work, it aims to contribute to the literature by presenting up-to-date information and different opinions.

The organization of the paper is as follows: Firstly, information about the brief history of risk and risk management in banking sector is discussed based on an approach to the future of banking risk management by providing facts from the banking sector and global financial markets. Secondly, relevant literature is presented to identify the current business risk management environment in financial markets and the position of the banks. Thirdly, the future trends in banking risk management functions and the reason behind challenges, opportunities and threats for the banking sector are examined. Especially, the digital risks, cyber risks and the role of Chief Risk Officers (CRO) and Chief Strategy Officers (CSO) in banking sector are discussed. A risk management function to cope not only with the traditional risks, but with new risk types arising from digitalization and innovation is 
proposed. In addition, the effectiveness of Basel Standards and IFRS 9 are discussed to discover the regulatory environment, risk talent and culture for future bank supervision approaches. Fourthly, risk management practices of Turkish Banks are briefly summarized to determine the needs and expectations in Turkey. Finally, some policy recommendations are made for best practices in banking risk governance strategies to stakeholders, depending on the future trends and challenges in global financial markets to contribute to the relevant literature.

\section{LITERATURE REVIEW}

Although risk management is not a new concept in the literature, it is renewed the attention after the global financial crises and corporate scandals. Alteration and adjustment is happening in each and every kind of banking system. The design and implementation of risk management should be "bank-specific" and bank management should encourage developing key risk indicators (KRIs) to facilitate effective monitoring of potential risk events as early warning mechanism based on technological trends and big data analytics. Considering this fact, risk management is relatively recent corporate function in banking sector. The very first risk management department was established in 1987 in a bank- namely Merrill Lynch (Dionne, 2013:2-5). Hence, the milestones of risk management are summarized in Appendix 1 .

The origin of contemporary finance theory is commonly related with the seminal paper of Louis Bachelier back in 1900. Louis Bachelier was the very first to apply Brownian motion to examine fluctuations in financial assets. Unfortunately, there was no proper research on the prices of financial assets until the 1930s. The fundamental studies on the financial theory have started in the 1950s and 1960s with the attempt of the well-known researchers such as Markowitz, Lintner, Treynor, Sharpe, and Mossin. In this way, "the modern theory of portfolio choice based on the CAPM (Capital Asset Pricing Model)" was introduced in the literature. There were revolutionary papers and empirical works in finance, which brought Nobel Prizes to these researchers in this period. Nevertheless, the major financial risk management tools and techniques were introduced in the early 1970s and the leading theoretical models of modern risk management were published in the literature (Thodla, 2014: 7-13).

Black and Scholes's model is certainly the most favored of these former financial risk management models. Black and Scholes were the very first researchers, who had proposed a comprehensive equation for the option pricing and derivatives products (Ross, 2014: 619620 ). Their proposed equation for option pricing was considered extremist. Hence, at first, the leading finance journals rejected this paper and they did not want to publish its original version. Afterwards, it was accepted and published in the Journal of Political Economy, in 1973. After that year, Merton issued an article as an extension of this model in another journal, namely the Bell Journal of Economics and Management Science. Derivatives products expanded so quickly in the global financial markets with various asset backed contracts especially swaps and OTC or over the counter options (Dionne, 2004: 178-180). 
The usage of derivatives accelerated due to increasing technological advancements in banking sector and especially new statistical tools made it so easy to apply mathematical finance. These new statistical tools are practical in the estimation of default risk, credit risk and risk pricing as a whole (Jorion, 2006: 13-15). For this reason, credit risk scoring and credit risk management in banking sector have become widespread.

There were two well-known internal risk management models, namely "RiskMetrics and CreditMetrics", which were introduced by JP Morgan in 1994 and 1997 respectively. RiskMetrics is used for measuring market risk and CreditMetrics is used for measuring credit risk. These two models focused on the portfolio form of risk measurement based on inter dependencies and they rely upon value at risk approach to quantify the aggregate portfolio risk. After the publication of "RiskMetrics model", there was a great acceptance of the Valueat-Risk (VaR) risk measure among risk management experts and academics (Artzner et.al, 1999: 205-210; Basak and Shapiro, 2001: 372-375). In addition, Value at Risk approach has been used to investigate the loss amounts arising from the misuse of derivatives in 1994 financial scandals such as Barings and Orange Country. It is not only the 1994 financial crisis, but also there were three major credit crises followed in the financial markets. They were marked as shortfall quickly turned into default risk, namely the Russian crisis, the Asian crisis, and the fall of Long Term Capital Management (LTCM). Due to the financial crisis and scandals, risk management has been a corporate concern and priority issue since the late 1990s (Tapen and Cham'u, 2000: 8-10). Adequate capital reserve requirement became the most important distress in the early 2000s following the defaults in the late 1990s and specifically the Enron bankruptcy in 2001 (Jeune, 2015: 7-9; Berkowitz and O'Brien, 2002: 1093-1095).

In addition to changing the process of credit risk management, there were new rules and regulations for operational risk management introduced by the Basel Standards to overcome this situation. It is a fact that Basel Standards provided a distinct regulative framework which led to a change in the risk vision of the banking sector (Danielsson et.al, 2001:4-6). The above-mentioned new statistical tools are relevant and reliable instruments for measuring regulators capital requirements of banks under Basel Standards (Field, 2003: 74-80). The year 2014 has been memorable for Basel city that has a synonym name with banking regulation when the Basel Committee celebrated its 40th anniversary. However, regarding the existence of Basel Standards more than four decades, they prevent neither financial crisis nor financial scandals (Basel, 2015; Basel, 2016). Hence, the business conditions, in which conventional banks are working, seem to be remarkably shifting. This situation has participated to the launch of sophisticated risk management practices and the commencement of new controls and the inclusion of a risk culture into banking risk management function, where historically the focus had been on excessive risk taking. In other words, banking regulation has contributed to the development of structures and processes for the risk management as well as the establishment of enterprise wide risk management and internal control framework.

Van Steenis (2019) prepared and submitted a report to the Bank of England in order to explain how finance would serve the economy in the future. According to the findings of this report, banking business model will be different in the mid-2020s due to disruptive forces in the global financial markets and change in digital payment systems. In that scenario, change will be the one and only element that is certain for risk professionals in financial institutions. 
In addition, the agenda for risk professionals will involve not only financial type of risks but also non-financial risks. According to the survey findings in the Global Risks Report of World Economic Forum (WEF) (2019), perceived significance of impact and likelihood of non-financial risks in top five global risks has risen over the last 10 years. These survey findings are related to the improvement of a more advanced approach to non-financial risks in the world, which are difficult to measure in the past (WEF Global Risk Report, 2019:6-7).

According to Dionne (2013), risk management is a comparatively new corporate goal in banks. The notion of risk management in the banking sector was reformed in the 1970s. This was related to the need for a change in the financial risk management structure for numerous organizations including banks, insurance companies, and non-financial enterprises. Such organizations are facing various risk related to price fluctuations in interest rates, stock prices, exchange rates, and commodities. In this respect, it is important to analyze the future trends in banking risk management to take necessary precautions before it is too late.

There is a survey conducted by Jeune (2015) to identify the best practices in key risk management areas within European and US banks. The major hypothesis of this research is that the banks with good risk governance are most likely to preserve stakeholder value over the long term. According to the empirical findings of this research, bank management should go beyond the standard checklist approach to achieve robust risk management culture. The reasons for shortcomings within bank risk organizations include lack of risk management expertise, limited authority of chief risk officers (CRO) and lack of independence related to audit, risk and control functions (Jeune, 2015: 5-8). In this context, changing the whole culture of banks to achieve good governance will take long time, however it is possible to improve risk organization as a first step. In the next section, information about the future trends in the risk organizations of banking sector are provided.

\section{FUTURE TRENDS IN RISK ORGANIZATIONS OF BANKING}

There are diverse changes and challenges which have great potential to affect the future of risk management in banks. These changes and challenges force shaping the economy and hence, they have significant impacts on the financial markets and the banks as summarized in Table 1. Considering information provided in Table 1, banks should alter their risk organizations to adapt to these changes and challenges by establishing early warning mechanisms. In addition, banks need better tools and techniques to achieve effective and efficient risk management processes.

Table 1. Changes and Challenges Forcing the Economy, Financial Markets and Banks

\begin{tabular}{l|ll}
\hline $\begin{array}{l}\text { Changes and Challenges } \\
\text { Forcing in the Economy }\end{array}$ & $\begin{array}{l}\text { Impacts on the } \\
\text { Financial Markets }\end{array}$ & Impacts on the Banks \\
\hline $\begin{array}{l}\text { Platform-based economy } \\
\text { Gig and sharing economy } \\
\text { Big data }\end{array}$ & Shift to digital & $\begin{array}{l}\text { Next generation } \\
\text { payment systems } \\
\text { Open banking }\end{array}$ \\
$\begin{array}{l}\text { Automation \& machine learning } \\
\text { Digital Currencies }\end{array}$ & & \\
\hline $\begin{array}{l}\text { Low-carbon economy } \\
\text { Environment }\end{array}$ & Demographics & $\begin{array}{l}\text { Global standards for } \\
\text { slimate change }\end{array}$ \\
\end{tabular}




\begin{tabular}{|c|c|c|}
\hline Ethics & & $\begin{array}{l}\text { Financial Disclosures } \\
\text { (TCFD) }\end{array}$ \\
\hline $\begin{array}{l}\text { Cyber-crime } \\
\text { New laws and regulations } \\
\text { Cloud technology and data } \\
\text { storage }\end{array}$ & Digital regulation & $\begin{array}{l}\text { New business model } \\
\text { Digital strategy } \\
\text { Quality assurance } \\
\text { Rethinking three lines } \\
\text { of defense }\end{array}$ \\
\hline
\end{tabular}

Source: van Steenis, 2019.

The major risk management tools and techniques are presented in Table 2, which is used for analyzing and measuring non-financial (operational) risks and financial risks such as market risk, credit risk and liquidity risk respectively.

Table 2. The major risk management tools and techniques for banking sector

\begin{tabular}{l|llll}
\hline Tools & $\begin{array}{l}\text { Market } \\
\text { Risk }\end{array}$ & $\begin{array}{l}\text { Credit } \\
\text { Risk }\end{array}$ & $\begin{array}{l}\text { Liquidity } \\
\text { Risk }\end{array}$ & $\begin{array}{l}\text { Operational } \\
\text { Risk }\end{array}$ \\
\hline Risk Limits & $\sqrt{ }$ & $\sqrt{ }$ & $\sqrt{ }$ & \\
Credit Risk limits & & $\sqrt{ }$ & & \\
Value at Risk & $\sqrt{ }$ & & & \\
Earnings at Risk & $\sqrt{ }$ & & & $\sqrt{ }$ \\
Expected Shortfall & $\sqrt{ }$ & & $\sqrt{ }$ \\
Economic Value Stress Testing & $\sqrt{ }$ & $\sqrt{ }$ & $\sqrt{ }$ \\
Economic Capital & $\sqrt{ }$ & & & $\sqrt{ }$ \\
Risk Sensitivities & $\sqrt{ }$ & & $\sqrt{ }$ \\
Risk Assessment (RCSA) & & & $\sqrt{ }$ \\
Operational Risk Losses & & & $\sqrt{ }$ \\
Loss Distribution Approach & & $\sqrt{ }$ & \\
Scenario Analysis & $\sqrt{ }$ & $\sqrt{ }$ & \\
Tail Risk Capture & $\sqrt{ }$ & $\sqrt{ }$ & \\
Stress Testing & & $\sqrt{ }$ & \\
Scoring Models & & $\sqrt{ }$ & \\
Rating Models & & $\sqrt{ }$ & \\
Exposure & & & & \\
- Probability of Default & & $\sqrt{ }$ & \\
- Loss Given Default & & & \\
- Exposure at Default & & & \\
Back Testing & & $\sqrt{ }$ & \\
\hline
\end{tabular}

Source: Leo et al., 2019.

In this context, there are major trends which shape the role of the risk organization of the future banking related to regulations, customer expectations, smart technologies, and emergence of new risk types.

\subsection{Expansion of Regulation}

As a result of financial crisis, new rules, regulations and updated standards are introduced in banking sector. There are new directives such as IFRS 9 - Financial Instruments (IFRS: International Financial Reporting Standard), Basel Standards (mainly the fundamental review of the trading book and the standardized approach for measuring counterparty credit risk) and the European Union's General Data Protection Regulation (EBA, 2017). It seems 
that these new directives will continue to dominate resources in many banks while Basel III reforms (Basel IV) could increase the impact of any of those directives. In this respect, there will be a remarkable change in the relationship between banks and regulators with regard to reporting, measuring and handling risk ${ }^{1}$.

Figure 1. Regulatory Triangle for Banks

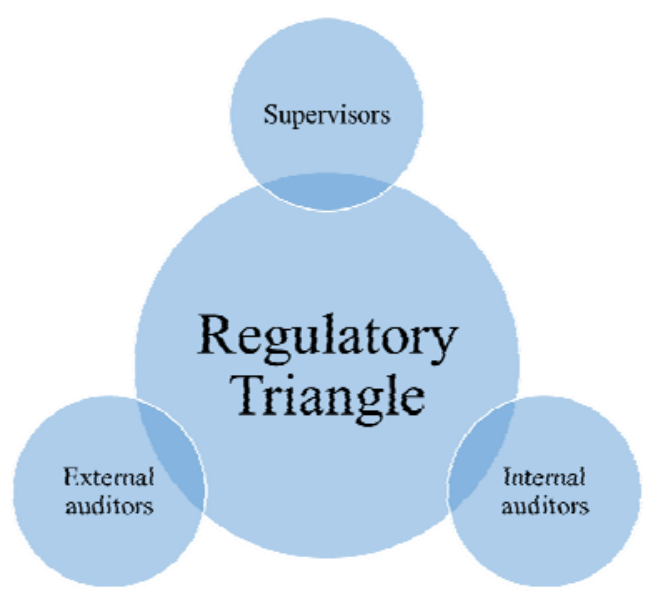

Source: BIS, 2015.

In this respect, the BIS (2015) proposed the "regulatory triangle" as supervisory authorities, internal auditors and external auditors in order to strengthen the internal control environment for banks (Figure 1).

\subsection{Expansion of Customer Expectations}

It is a fact that a tough competitive business environment in a fragile economic context has created challenges for banking sector in the last decade. The recent regulatory and technological requirements have significant implications across risk management strategy of banking including adjusting certain product lines and/or business activities. As in other sectors, it is more advantageous and cost-effective to ensure the satisfaction of the existing customers in the banking sector than to attract new customers. On the other hand, competition enforces bankers to gain more new customers to be more efficient, economic and in this context, they usually apply an expansionary marketing and sales strategy. It should be noted that operational expertise is the part of first customer impression. Hence, having the proper experts in the onboarding process in banking not only provides the chance with certain and comprehensive responses, but also brings the stage for operational excellence and accurate

\footnotetext{
${ }^{1}$ For instance, the major rules and recommendations at EU level include:

(1) Bank for International Settlements (BIS), Principles for enhancing corporate governance (October 2010)

(2) European Banking Authority (EBA), Guidelines on internal governance (September 2011)

(3) Bank of England Prudent Regulation Authority (PRA) rule book Risk control: guidance on governance arrangements (last update January 2014)

(4) Financial Reporting Council (FRC) guidance on Risk Management Internal Control and Related Financial and Business reporting (September 2014)
} 
risk culture from day one. Otherwise, when onboarding process is not stable, it leads the banks to possible operational, financial and compliance risks including incorrect portfolio management, inaccurate documentation, and inefficient customer operations. As industry best practice, it is recommended to have a formal policies and procedures for documentation, review, and approval process; portfolio management guideline testing before funds acceptance or trading and also a workflow management and reporting tools to control and follow up process could be useful (Warwick, 2016: 6-8).

\subsection{Expansion of Smart Technologies}

There will be more advanced tools $\&$ techniques used widely. Among these trends, Big Data technology has the most powerful instrument to help banks mitigate the profitability impacts of regulation, make strategic business decisions, and reduce operational costs. On the other hand, innovation can be witnessed everywhere in banking sector. Data analytics continues to reinvent decision making. For instance, there are software robots in bank operations and humanoid robots in branches. In the meantime, emerging technologies such as block chain and artificial intelligence (AI) are changing the essential services and technicalities of banking. Oliver Wyman (2017) states that the current recourse location in banking sector will dramatically change in the future which is shown in Figure 2. According to Oliver Wyman (2017), the traditional risk activities (50\% down to 25\%) will shift to strategic risk advice (20\% up to $35 \%$ ) and also the importance of management operations will increase ( $15 \%$ up to $25 \%)$.

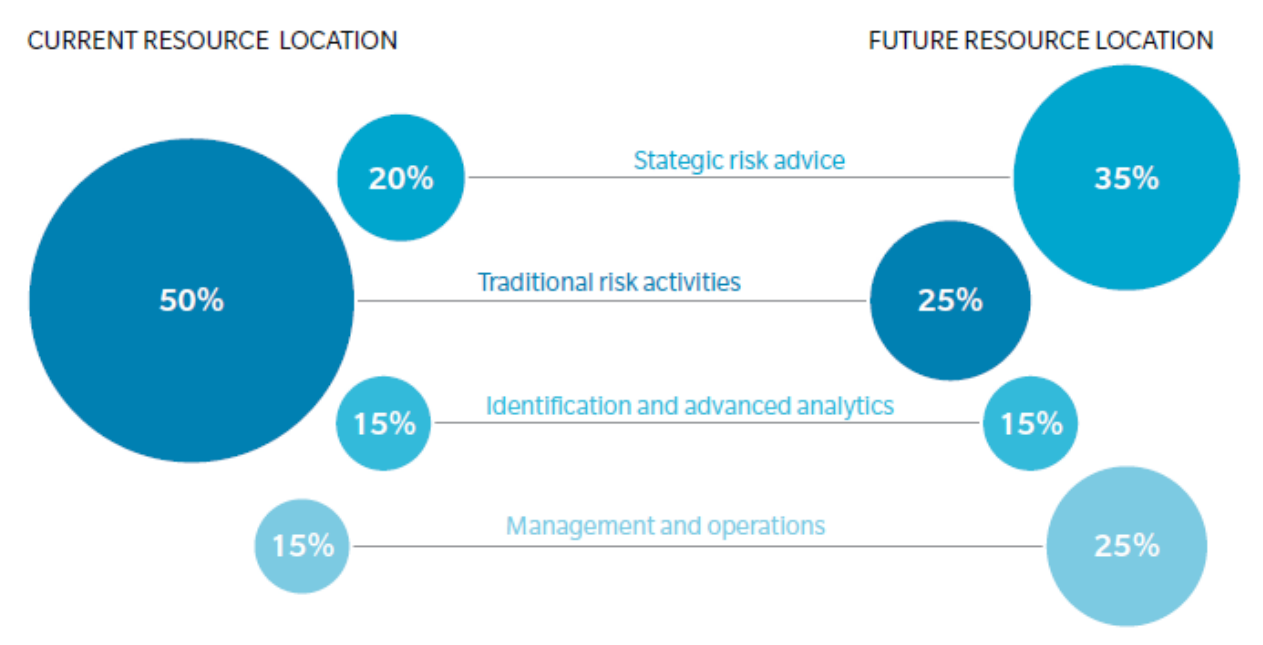

Figure 2. Current and Future Resource Location in Banking Sector

Source: Oliver Wyman, 2017. 


\subsection{Emergence of New Risk Types}

Due to innovative products and services, there will be emerging risk types such as model risk, cyber risk and contagion risk. According to IIF and McKinsey (2017), there will be "Nerve Centers" in banks with a centralized and forward looking risk identification approach across different risk types. In this way, the structure and risk responsibilities in the three lines of defense will change for banking sector, i.e. it is expected that most of the operations move from the first line of defense to risk management groups ${ }^{2}$. Within an organization, the three lines of defense is expected to attain an effective management of risk and control. In order to reach this, the three lines of defense function must be properly established without any gaps, i.e. full coverage of risk versus control.

On the other hand, Mongiardino (2019) argues that banks should consider climate change as part of the financial risk management process. Hence, climate change is not only related to reputational risk, but also it should be treated as an integral part of financial risks. According to this author, the banks' business model and risk management process must be forward looking view. Likewise, Prudential Regulation Authority (PRA) (2018) indicates the need for financial institutions to develop an approach to analyze financial risks arising from climate change. In order to achieve a forward looking view in the financial risk management process; firstly, there should be an interdisciplinary approach and collaboration across business functions and more importantly coordination between business and risk management units. Secondly, the learning organization approach should be applied. Thirdly, there must be a common language and risk culture to establish a strong communication channel between management and operational levels within the organization (Arner et al., 2015: 12-15).

\subsection{Expansion of Risk Organization}

It is a fact that banks are operating in the risk business (Tursoy, 2018: 6-7). The role of risk function will be strategic. Considering these circumstances, the risk function of banking is developing both as part of these trends and in reaction to them. In other words, these innovations are changing the way the risk function operates, while at the same time, the risk function has to adapt to the rapid pace of innovation across most areas of the bank as well (Haugh, 2010: 11-15). Currently, risk professionals in banks are dealing with a wide range of financial risks (Figure 3) and they have clearly been building their cyber risk capabilities. However, there is still a shortage of talent in this and other specialist areas.

As a solution to this shortage of talent, the demand for Chief Risk Officer (CRO) and Chief Strategy Officer (CSO) is increasing in banking sector. Recruitment rates of CRO and equivalent positions, which were 64\% in 2002, reached 92\% as of 2016 as shown in Figure 4 .

\footnotetext{
${ }^{2}$ IIF and McKinsey (2017). The Future of Risk Management in The Digital Era. Survey Report. October 2017. pp.10-12.
} 


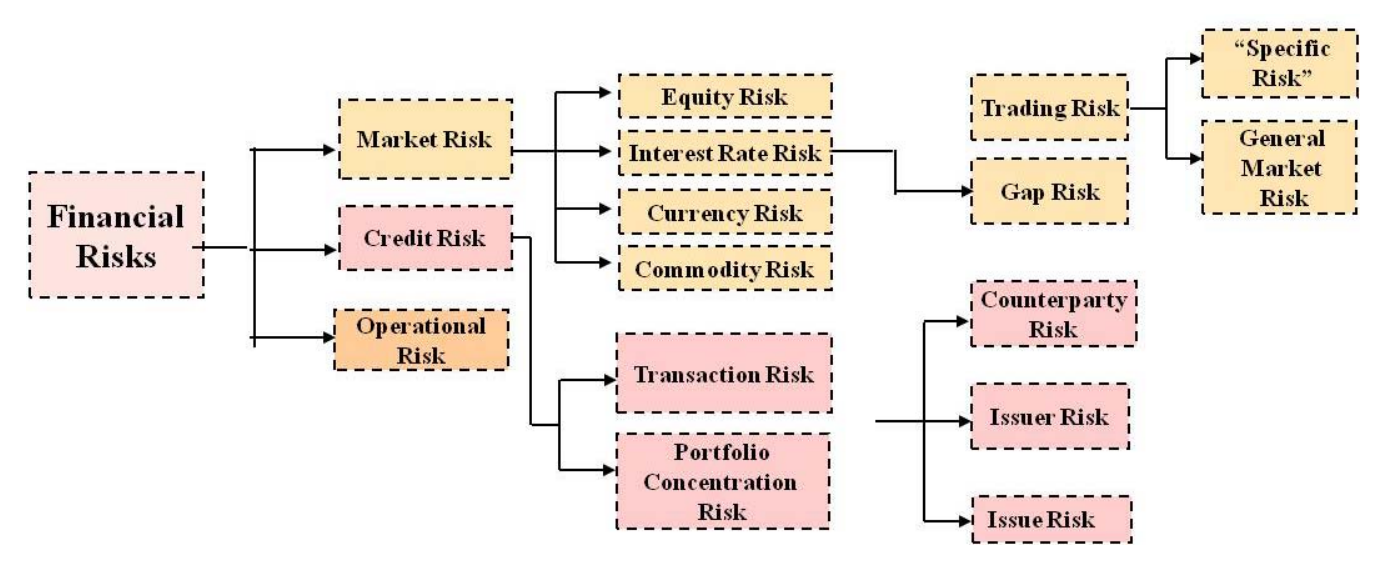

Figure 3. The Hierarchy of Financial Risks

Source: Crouhy et al., 2014.

According to the findings in Deloitte's Global Risk Management Survey (2017), there seems to be a big battle for risk management talent in banking sector. Due to increasing regulatory requirements and cybersecurity issues, there has been greater competition for attracting and retaining professionals with risk management skills and experience. Cybersecurity is a serious concern for the banking sector and hiring cybersecurity skilled talent is extremely difficult (Deolitte, 2017: 4-7).

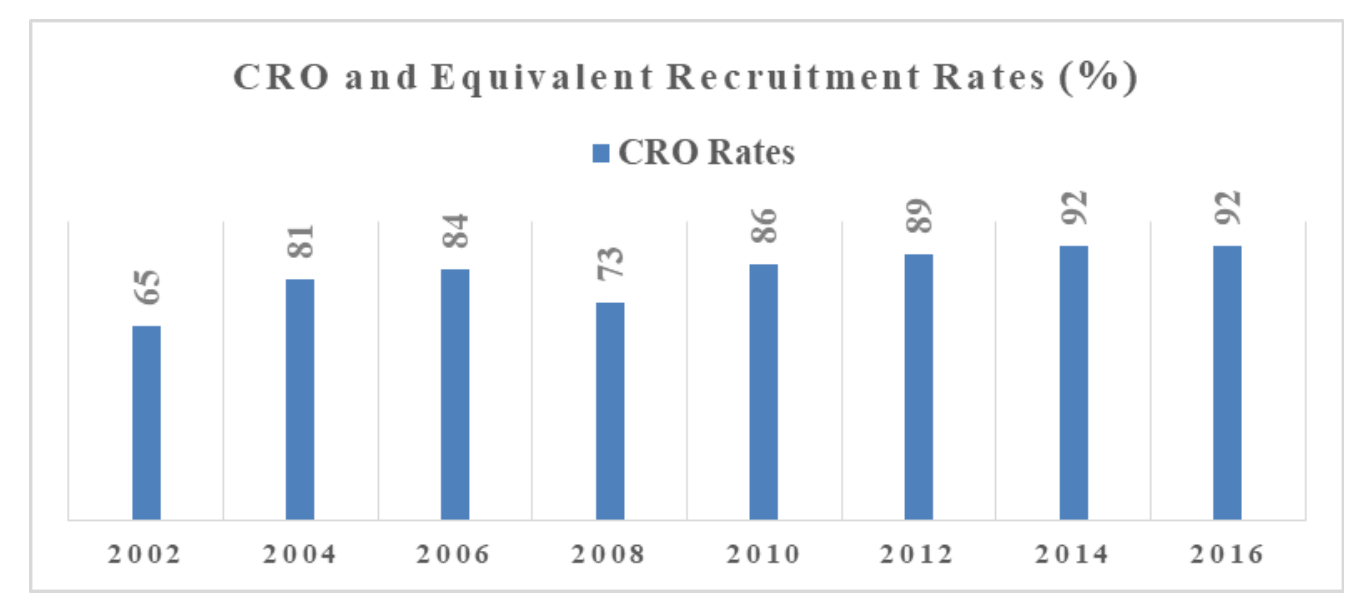

Figure 4. Recruitment Rates of CRO and Equivalents

Source: Deloitte, 2017.

There is a significant effect of digitalization on the risk management functions' instructions, role, and set-up based on the three lines of defense approach. This situation also requires the skills, abilities, organizational culture, and ways of working required to serve a digitized risk function. Risk executives start to deal with more strategic issues since almost all the transactions will be automated in the banking operations. In other words, all routine works 
will be automated and risk executives will be required to rely on advanced analytics to generate insights to detect emerging risks.

\subsection{Expansion of Cost Cutting Policies}

Cost cutting policies will continue in banking. It becomes a priority for banking sector to use robotics process automation (RPA) as much as possible to automate routine tasks. According to Crawford (2017), as a management concept, risk management and what is considered "good management" become impossible to differentiate, so it is considerable that good management should not be restricted to a vision based on "compliance only" type approaches. Digitization in banking sector is used as a powerful tool for competitive advantages like increase in efficiencies and productivity, reduced losses, and enhanced customer experiences. Since digital transformation in banking sector occurs mostly with a "modular" approach rather than having a classical large scale IT re-structuring projects, higher impact areas could be targeted more accurately. Particularly, risk automations based on robotics with machine learning technologies improve the credit risk management processes with higher capability, frequency and volume of operational transactions. On the other hand, evolving cyber risks may lead to high operational losses, which cause offsetting the gains from digitization in banking sector. In order to avoid any potential losses arising from cyber risks, banks should take some necessary preventive measures. Banks may consider establishing a risk management program for digital transformation to protect their systems and also seize their relevant opportunities. A typical risk management program for this purpose is recommended with the following content: (1) big data governance and analytics (2) workflow technology and smart decision-making tools (3) talent and risk culture.

Big data governance and analytics is widely recognized by banking sector with the achievement of high performance at a low cost. According to International Data Corporation (IDC) (2019) survey results, big data brings a potential by being better and faster at a lower cost. The evolution of algorithmic trading will depend on smart machines with full support of automation and sophistication in the banking sector (IBM, 2017:3-5). On the other hand, the financial market structure will change in terms of volume, volatility, liquidity and spread with the development of artificial intelligence, which will bring new type of risks into the financial ecosystem. After the global financial crisis in 2008 and the increasing regulatory pressures, chief risk officers (CRO) and management boards in banks mostly focus on the risk convergence concept. Risk convergence means to have a vision of risk assessment, mitigation and reporting processes should be consolidated. This approach requires a new operating model in banking sector.

\section{RISK MANAGEMENT FRAMEWORK FOR BANKING}

Oliver Wyman (2017) recommends a business model for banks based on finance and risk reporting operations to improve risk management framework, which is shown in Figure 5 . 


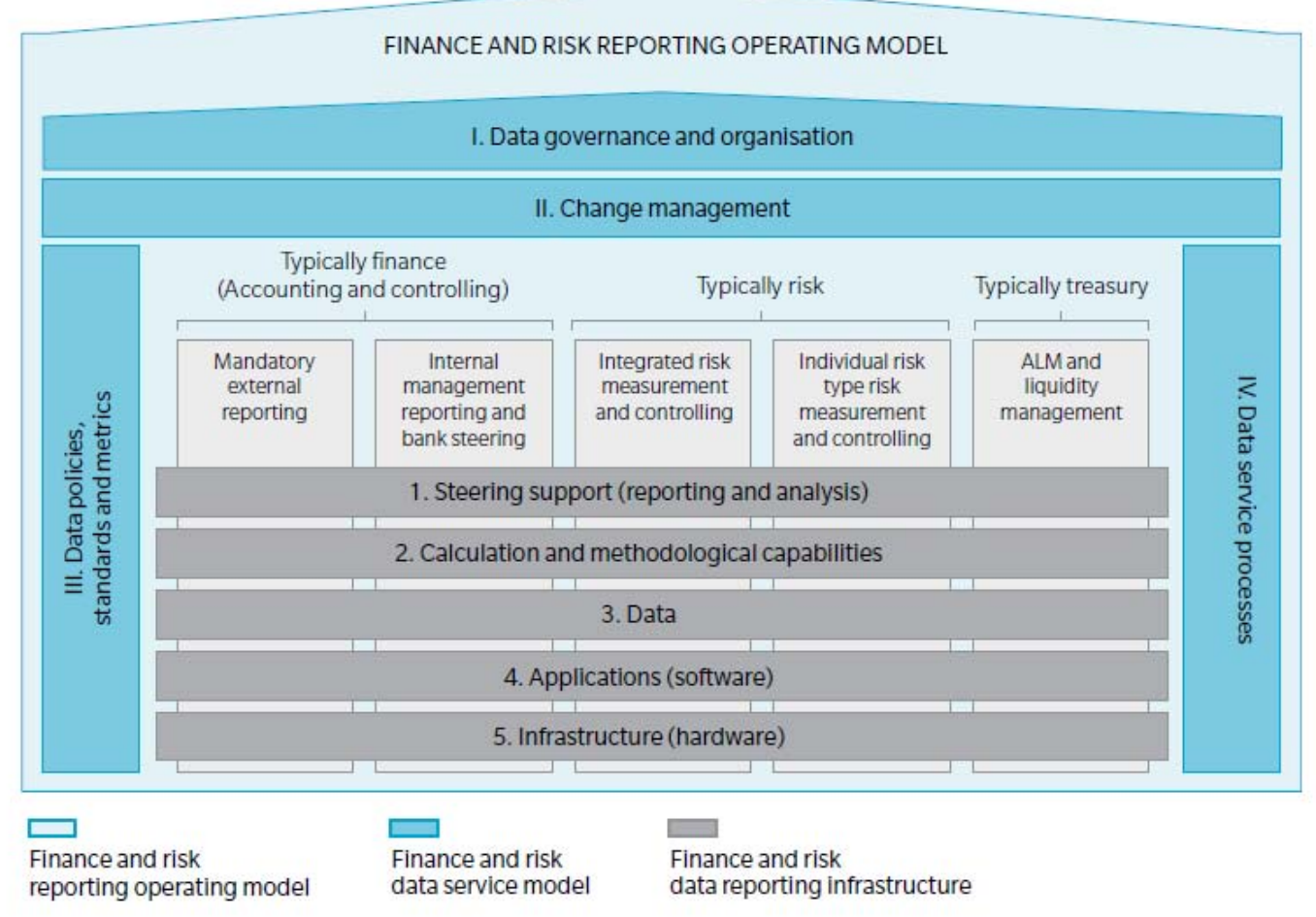

Figure 5. Business Model for Banks

Source: Oliver Wyman, 2017.

In this model, the first layer is the data governance and organization for the banks. This is because, banks are relatively more sensitive to the governance, privacy and data protection issues to build a lifetime relationship with their customers based on trust and assurance. The second layer is change management. Banking sector operates in a very dynamic business environment and change management should be done truly on time to cope with bulk of transactions, i.e. big data characterized by online and real time operations based on finance, risk and treasury management and reporting requirements. Therefore, Oliver Wyman (2017) argues that banks should have (1) finance and risk data reporting infrastructure, (2) finance and risk data service model and (3) finance and risk reporting operating model supported by the third layer, i.e. data policies, standards, and metrics. In the fourth layer, data service processes are established to coordinate finance, risk and treasury functions regarding the data governance and organization, and change management.

The business model is basically defining the major resources, roles and processes for the banking finance and risk reporting operations. In addition, there is a need for risk expertise to supervise and run this risk management framework. In this context, the board level risk committee (the Committee) takes crucial part to have oversight role (Kearney, 2014: $8-10)$. There is a global risk management survey conducted by Deloitte (2017) indicating that board-level risk committee is the most common one among financial institutions. The Committee should delegate responsibility to chief risk officer (CRO) when the CRO is in charge of all types of risks including both financial and non-financial risks. CRO should serve 
independently and transparently to increase the effectiveness of risk management process (Figure 6).

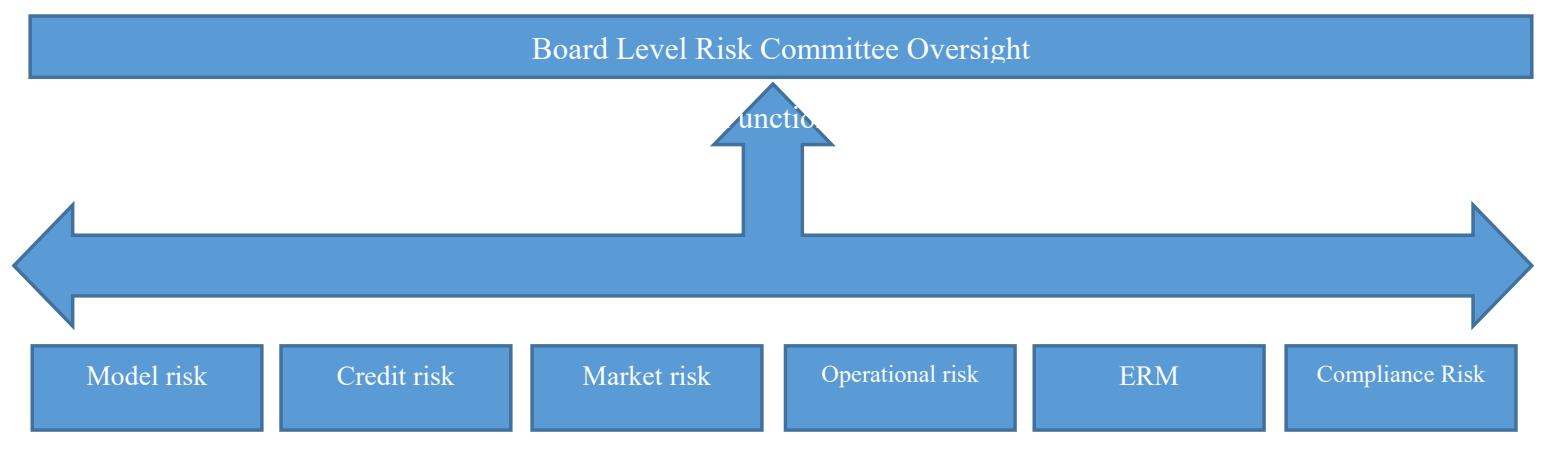

Figure 6. Simplified Risk Management Framework

Source: Jeune, 2015.

It should be noted that banks are mostly the best practice for the implementation of three lines of defense, which is shown in Figure 7. In this respect, not only the risk management function is responsible for the risk, but also the business units are accountable for the risks of their own activities to strengthen the risk management framework. In other words, efficiency of the first line of defense is treated as a good indicator of appropriate risk culture (IIA, 2013: 3-6; PwC, 2014 5-6; EY, 2015: 8-15; KPMG, 2017: 4-6)). On the other hand, Arndorfer and Minto (2015) prepared an Occasional Paper to recommend a new approach for the financial institutions and more specifically for banks about improving the three lines of defense model by taking this model further to reflect specific governance structures of regulated financial institutions. These authors argue that banks and insurance companies need "the four lines of defense" more rather than three lines of defense, because of the risky nature of the industry. They state that the supervisors and external auditors, who are formally outside the organization, are important actors in the financial industry. However, both the supervisors and external auditors should be the integral part of the financial institutions, with a specific role in the structure of the internal control system to cope with the particular risks inherent to such entities, including vulnerability to a systemic collapse (Arndorfer and Minto, 2015: 9-10). 


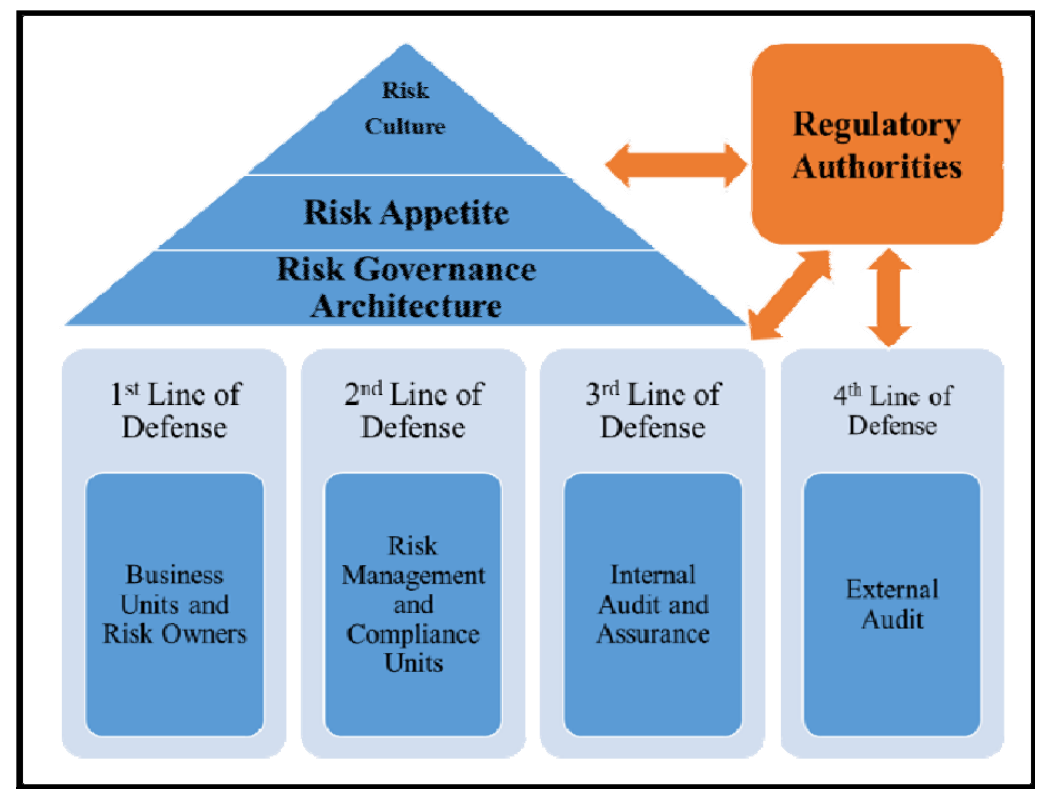

Figure 7. Risk Governance Structure in Banks

Source: Adapted from IIA, 2013 and BIS, 2015.

\section{RISK MANAGEMENT PRACTICES IN TURKISH BANKING SECTOR}

Turkey has demonstrated considerable flexibility. For this reason, Turkish banking sector suffered tolerably less from the financial crisis. On the other hand, there is a high rate of growth in loans in Turkey. This makes it debatable leading to higher levels of exposure to credit risk and vulnerability against financial shocks. With the introduction of BRSA's "Best Practices Guideline in Credit Management of Banks" in July 2014, Turkish banks conduct gap analysis. This kind of analysis is practical to establish the major needs of the principles that could affect their credit management process. Typical credit management process is based on the strategy, guidelines, rules, credit scoring, documentation and reporting, information technology, internal loan management systems, and related business units.

On the other hand, structural changes in Turkish banking sector are expected in the near future. These can be summarized as:

There will be a new operating model in Turkish banking sector by redefining the critical business processes to be centralized, transactions to be shifted from branch to other service delivery channels, and transaction types per different branch types to enhance competitiveness.

The banking system will be modified to build branch structure according to customer ownership and also there will be a structure for agent banking in rural areas to increase customer satisfaction.

The risk management strategy will be changing from segment based risk/profitability to managing total risk /profitability. In this way, integrated risk management approach will be applied to achieve best practices. 
- $\quad$ Turkish banking sector is dynamic and creative in nature and bankers consider having strategic partnerships with telecommunications and retail sectors to utilize more of the market potential.

- Last but not least, Turkish banking sector focuses on risk management strategies and risk intelligence to improve risk culture.

Hence, Turkish banking sector is strong with its technology enabled infrastructure and the adaptation capability related to the new tools and techniques used in financial engineering and product development is high. The future of banking risk management in Turkish market will be most probably the best practices in the world. This is due to the fact that after experiencing global financial crisis, Turkish banking sector has improved the capital structure and opened to financial innovations.

\section{CONCLUDING REMARKS}

Due to the nature of the banking sector, its risk diversity and risk level are high. In this context, the importance of risk organization is clear. The scope of the risks, that banks must cope with while operating in the global competitive environment, is increasing day by day. It is a fact that there is a tremendous change and adaption process within the banking risk management system. Technology enables banks to have a full transparency in risk management process. Bank risk executives' roles evolve from operative to strategic with robust risk culture holding the key to success.

Risk management activities in the banking sector are intertwined with big data analytics. In this context, there is a need for integrated risk management (ERM) approaches and professionals specialized in the field of risk. The banking sector is highly influenced by technological innovations and this also brings forth cyber security risks. In the banking sector, where risk management is strategically so important, it is critical that risk organization be accurate and functional. In this context, adherence to legal regulations is not sufficient. The integration of digitalization into the risk intelligence applications is the most needed course of action in banking sector. The most important reason for this is the necessity to make big data based analysis. Furthermore, it is recommended that the members of the risk committee have expertise and experience in risk management. It is important to remember that risk is the responsibility of all employees in order to sustain the risk-related structure. Therefore, for effective risk management and the true risk culture, it is important to implement the three lines of defense without exception. By the introduction of the four lines of defense, there is a need for strong collaboration between internal auditors, supervisors and external auditors in order to achieve a proactive relationship in the future of risk management in banking.

In the Turkish banking sector, the measures taken and risk organization related to risk management are generally above the maturity level. When the dynamic structure of financial markets is taken into consideration, it can be stated that the banks' ability to detect risks early is sufficient. However, it may be useful to review and strengthen the technical infrastructure related to cyber security. 


\section{REFERENCES}

Arner, D.W., Barberis J.,- Buckley R. (2015), “The Evolution of Fintech: A New Post-Crisis Paradigm, SSRN Electronic Journal 47(4):1271-1319 · January 2016, University of Hong Kong Faculty of Law Research Paper No. 2015/047, DOI: $10.2139 /$ ssrn.2676553.

Accenture (2017), "The Hidden Value Of Risk In Banking", Banking Report, [online] Available https://www.accenture.com/t20170905T060353Z_w_/ieen/_acnmedia/PDF-60/Accenture-Global-Risk-Study-2017-Banking-Report.pdf, $(10.05 .2019)$

Artzner , P.- Delbaen, F.- Eber, J.M.- Heath, D. (1999), “Coherent Measures Of Risk”, Mathematical Finance, 9, pp.203-228.

Arndorfer I. - Minto A., (2015), "The "four lines of defense model" for financial institutions", Occasional Paper No. 11, Bank for International Settlements. https://www.bis.org/fsi/fsipapers11.pdf (08.10.2019)

Aveni, Tyler (2015), "New Insights Into An Evolving P2P Lending Industry: how Shifts In Roles And Risk Are Shaping The Industry", Credit Suisse, [online] Available https://www.findevgateway.org/sites/default/files/publication_files/new_insights_into _an_evolving_p2p_lending_industry_positiveplanet2015.pdf ${ }^{-}(12.06 .2019)$

Basak , S.- Shapiro, A., (2001), "Value-at-risk Based Risk Management: Optimal Policies And Asset Prices", Review of Financial Studies 14, 371-405.

Basel Committee on Banking Supervision , (2016), Amendment to The Capital Accord To Incorporate Market Risks, Bank for International Settlements.

Basel Committee on Banking Supervision, (2015), Supervisory Framework For The Use Of "Backtesting" In Conjunction With The Internal Models Approach To Market Risk Capital Requirements, Bank for International Settlements.

BDDK, (2010), Bankacıllk Sektörü Basel II İlerleme Raporu, Şubat 2010, [online] Available http://www.bddk.org.tr/WebSitesi/turkce/Basel II/7613\%C4\%B0lerlemeRaporu-0210.pdf, (20.05.2019)

Berkowitz, Jeremy - James, O'Brien (2002), "How Accurate Are Value-At-Risk Models at Commercial Banks?”, Journal of Finance 57, pp. 1093-1111.

Bozkuş, Sezer (2005), "Risk Ölçümünde Alternatif Yaklaşımlar: Riske Maruz Değer (VaR) ve Beklenen Kayıp (ES) Uygulamaları", Cilt 20, sayı 2, ss. 27-45. Dokuz Eylül Üniversitesi İ̈BF Dergisi, [online] Available https://iibfdergi.deu.edu.tr/index.php/cilt1-sayi1/article/view/190/pdf_169, (15.05.2019)

Committee of Sponsoring Organizations of the Treadway Commission -COSO (2017), " Enterprise Risk Management Integrating with Strategy and Performance Executive 
Summary ", [online] Available https://www.coso.org/Documents/2017-COSO-ERMIntegrating-with-Strategy-and-Performance-Executive-Summary.pdf , (15.05.2019)

Crawford, Jason (2017), "Regulation's Influence on Risk Management and Management Control Systems in Banks", Uppsala Universitet, Department of Business Studies, [online] Available https://uu.divaportal.org/smash/get/diva2:1151290/FULLTEXT01.pdf, (15.05.2019)

Crouhy, Michel - Robert, Mark, - Dan, Galai (2014), The Essentials of Risk Management, McGraw Hill Education.

Danielsson, J. - Embrechts, P. - Goodhart, C. - Keating, C. - Muennich, F. - Renault, O. Song Shin, H. (2001), An Academic Response to Basel II, Working Paper, London School of Economics.

Dionne, G., (2004)." The Foundations Of Risk Regulation For Banks: A Review Of The Literature. In: The Evolving Financial System And Public Policy", Proceedings of a conference held by the Bank of Canada, 177-215, Ottawa, Canada.

Dionne G., (2013), " Risk Management: History, Definition And Critique", HEC Montreal Department of Finance, [online] Available https://papers.ssrn.com/sol3/papers.cfm?abstract_id=2231635, (15.05.2019)

Deloitte (2017), "Strategic Risk Management in Banking", [online] https://www2.deloitte.com/content/dam/Deloitte/lu/Documents/financialservices/Banking/lu_inside_issue14_strategic_risk_management.pdf , (15.05.2019)

EBA (2017), "Risk Assessment Of The European Banking System", European Banking Authority, [online] https://www.eba.europa.eu/documents/10180/2037825/Risk+Assessment+Report++November+2017.pdf , (15.05.2019)

EY (2015), "Rethinking Risk Management Banks Focus On Non-Financial Risks And Accountability", 2015 risk management survey of major financial institutions, [online] http://www.ey.com/Publication/vwLUAssets/EY-rethinking-riskmanagement/\$FILE/EY-rethinking-risk-management.pdf, (10.05.2019)

Field, P., (2003), Introduction to Modern Risk Management, A History. Incisive RWG, Haymarket House, London.

Garisde Thomas and Jonathan Mitchell (2017), "The Future Of Risk Management Ten Years After The Crisis", [online] http://www.oliverwyman.com/content/dam/oliverwyman/v2/publications/2017/sep/OW-Future-of-Risk-2017.pdf , (12.05.2019)

Jorion P., (2006), Value at Risk: The New Benchmark for Managing Financial Risk, McGraw-Hill, 3rd Edition. 978-0-07-146495-6

JP Morgan, (1996), Riskmetrics - Technical Document, JP Morgan, Fourth Edition. 
Jeune Solange Le (2015), "Banks: a New Approach To Risk? Governance, Culture And Risk In A Revamped Banking Industry", Schroders press release, Jan 2015, [online] https://www.schroders.com/en/sysglobalassets/staticfiles/schroders/sites/global/pressreleases/banks-a-new-approach-to-risk.pdf , (12.05.2019)

Haugh Martin, (2010), "Risk Measures, Risk Aggregation and Capital Allocation", [online] http://www.columbia.edu/ mh2078/RiskMeasures.pdf, (12.05.2019)

Institute of Internal Auditors (IIA) (2013), IIA Position Paper: The Three Lines of Defense in Effective Risk Management and Control, https://na.theiia.org/standardsguidance/Public\%20Documents/PP\%20The\%20Three\%20Lines\%20of\%20Defense $\%$ 20in\%20Effective\%20Risk\%20Management\%20and\%20Control.pdf

IBM (2017), "Future of Risk Management", [online]( https://www01.ibm.com/events/wwe/grp/grp304.nsf/vLookupPDFs/Neil\%20Dodgson\%20Presenta tion $\% 20$ The $\% 20$ Future $\% 20$ of\%20Risk\%20Management/\$file/Neil\%20Dodgson $\% 20 \mathrm{P}$ resentation\%20The\%20Future\%20of\%20Risk\%20Management.pdf (12.05.2019)

IIF and McKinsey (2017), "The Future Of Risk Management In The Digital Era", [online] https://www.iif.com/system/files/32370132_the_future_of_risk_management_in_the digital_era_-_iif_and_mckinsey.pdf, (12.05.2019)

International Data Corporation (IDC) (2019) "IDC FutureScape: Worldwide Financial Services 2019 Predictions", [online] https://www.idc.com/getdoc.jsp?containerId=US44567818, (10.05.2019)

Kearney A.T. (2014), "Banking Strategies for Future", [online] Available https://www.atkearney.com/documents/10192/4598780/Banking+Strategies+for+the+ Future.pdf/cc0f08b2-e5f6-49bf-899d-d1699f45dec0, (18.05.2019)

KPMG, (2017), "Capital Adequacy and Risk Diversification for Banks and Securities Dealers", [online] Available https://assets.kpmg.com/content/dam/kpmg/ch/pdf/chordinance-concerning-capital-adequacy-en.pdf (14.05.2019)

Leo, M., Suneel Sharma - K. Maddulety (2019), "Machine Learning in Banking Risk Management: A Literature Review", MDPI, Basel, Switzerland. https://www.researchgate.net/publication/331538099_Machine_Learning_in_Banking _Risk_Management_A_Literature_Review (19.09.2019)

Mongiardino, A. (2019), "Challenges in Managing Financial Risk in the Future: A Practitioner's Perspective", 10th Risk Summit, Cambridge Centre for Risk Studies, https://www.jbs.cam.ac.uk/fileadmin/user_upload/research/centres/risk/downloads/192 006_risksummit_presentation_mongiardino.pdf, (22.09.2019)

Merton, R. C. (1973), "Theory of Rational Option Pricing”, Bell Journal of Economics and Management Science, 4 (Spring, 1973), 141-183.

Oliver Wyman (2017), "The State of the Financial Services Industry 2017 -Transformıng For Future Value", [online] https:/www.oliverwyman.com/content/dam/oliver- 
wyman/v2/publications/2017/jan/The\%20State\%20of\%20the\%20Financial\%20Servic es\%20Industry\%202017.pdf (14.05.2019)

Stulz, R.M., (2003), Risk Management and Derivatives. Thomson South-Western, USA.

Stulz, R.M., (1996), Rethinking risk management. Journal of Applied Corporate Finance 9, pp.825 .

Prudential Regulation Authority (PRA) (2018), "Transition in Thinking: The Impact Of Climate Change On The UK banking sector", Policy Statement, https://www.bankofengland.co.uk/-/media/boe/files/prudential-

regulation/report/transition-in-thinking-the-impact-of-climate-change-on-the-ukbanking-

sector.pdf?la=en\&hash=A0C99529978C94AC8E1C6B4CE1EECD8C05CBF40D

PwC (2014)," Retail Banking 2020 Evolution or Revolution?", [online] https://www.pwc.com/gx/en/banking-capital-markets/banking-2020/assets/pwc-retailbanking-2020-evolution-or-revolution.pdf (10.05.2019)

Ross, S.M. (2014), Introduction to Probability Models Eleventh Edition, Elsevier Publications, ISBN 978-0-12-407948-9.

Tapen Sinha and Francisco Cham'U, (2000), "Comparing Different Methods of Calculating Value at Risk", [online] Working Paper Series, http://papers.ssrn.com/sol3/papers.cfm?abstract_id=706582\&rec=1\&srcabs=87288, $(12.05 .2019)$

Thodla Sekhar (2014), " Changing the Organizational DNA - The Spread of Risk Culture", Independent Professional Member - Board Governance Committees, National Bank of Fujairah, GARP, [online] http://www.garp.org/newmedia/presentations/changingtheorganizationaldna_sekhartho dla_111214.pdf, (12.05.2019)

Tursoy, T. (2018), "Risk management process in banking industry", Online at https://mpra.ub.uni-muenchen.de/86427/ MPRA Paper No. 86427, posted 02 May 2018 14:20 UTC.

Van Steenis, H (2019), "Future of Finance Review on the Outlook for the UK Financial System: What It Means for the Bank of England", Future of Finance Report, Bank of England, https://www.bankofengland.co.uk/report/2019/future-of-finance (20.10.2019)

Warwick Ashford (2016), "Financial institutions on high alert for major cyber attack," ComputerWeekly.com, February 11, 2016, [online] https://www.computerweekly.com/news/4500272926/Financial-institutions-on-highalert-for-major-cyber-attack , (15.05.2019)

World Economic Forum (WEF) (2019), Global Risks Report, Survey, http://www3.weforum.org/docs/WEF_Global_Risks_Report_2019.pdf ,(16.10.2019) 
Appendix 1: History of Risk Management

\begin{tabular}{|c|c|}
\hline Year & Milestones \\
\hline 1730 & First futures contracts on the price of rice in Japan \\
\hline 1864 & First futures contracts on agricultural products at the Chicago Board of Trade \\
\hline 1900 & Louis Bachelier's thesis "Theorie de la Speculation", Brownian motion \\
\hline 1932 & First issue of the Journal of Risk and Insurance \\
\hline 1946 & First issue of the Journal of Finance \\
\hline 1952 & Publication of Markowitz's article "Portfolio Selection" \\
\hline $1961-1966$ & Treynor, Sharpe, Lintner and Mossin develop the CAPM \\
\hline 1963 & Arrow introduces optimal insurance, moral hazard, and adverse selection \\
\hline 1972 & Futures contracts on currencies at the Chicago Mercantile Exchange \\
\hline 1973 & Option valuation formulas by Black and Scholes and Merton \\
\hline 1974 & Merton's default risk model \\
\hline 1977 & Interest rate models by Vasicek and Cox, Ingersoll and Ross (1985) \\
\hline $1980-1990$ & Exotic options, swaptions and stock derivatives \\
\hline $1979-1982$ & First OTC contracts in the form of swaps: currency and interest rate swaps \\
\hline 1985 & $\begin{array}{l}\text { Creation of the Swap Dealers Association, which established the OTC exchange } \\
\text { standards }\end{array}$ \\
\hline 1987 & First risk management department in a bank (Merrill Lynch) \\
\hline 1988 & Basel I \\
\hline Late $1980 \mathrm{~s}$ & Value at Risk (VaR) and calculation of optimal capital \\
\hline 1992 & Article by Heath, Jarrow and Morton on the forward rate curve \\
\hline 1992 & Integrated Risk Management and RiskMetrics \\
\hline 1994-1995 & $\begin{array}{l}\text { First bankruptcies associated with misuse (or speculation) of derivatives: Procter and } \\
\text { Gamble, Orange Country and Barings }\end{array}$ \\
\hline 1997 & CreditMetrics \\
\hline
\end{tabular}




\begin{tabular}{l|l}
\hline $1997-1998$ & Asian and Russian Crisis and LTCM collapse \\
\hline 2001 & Enron bankruptcy \\
\hline 2004 & New governance rules by Sarbanes-Oxley and NYSE \\
\hline 2007 & Basel II \\
\hline 2008 & Beginning of the financial crisis \\
\hline 2010 & Bitcoin and introduction of block-chain technology \\
\hline 2010 & Basel III \\
\hline 2014 & Dod-Frank Wall Street Reform and Consumer Protection Act \\
\hline 2018 & Basel Committee on Banking Supervision celebrated 40th anniversary \\
\hline
\end{tabular}

Source: Adapted from Dionne, 2013 and Thompson Reuters, 2019. 